\title{
PENGARUH DISIPLIN DAN KOMUNIKASI TERHADAP KINERJA GURU DI SMP 4 KECAMATAN SIAK HULU KABUPATEN KAMPAR
}

\author{
Taromi 1) \\ Hasnah Faizah AR 2) \\ Caska ${ }^{3)}$ \\ 1) Post Graduate Student of Riau University \\ 2) Lecturer of Education Management Study Programme PPs University of Riau \\ 3) Lecturer of Education Management Study Programme PPs University of Riau
}

\begin{abstract}
This research was conducted at SMP 4 in Kecamatan Siak Hulu Kampar District. In order to know and analyze the influence of work discipline on the performance of teachers of SMP Negeri 4 in Siak Hulu District Kampar regency, to know and analyze the influence of communication on the performance of teachers of SMP Negeri 4 in Siak Hulu District Kampar regency, to know and analyze the influence discipline work and communication on the performance of teachers SMP Negeri 4 in Siak Hulu District Kampar regency. Where the population is all teachers of junior high school 4 In Siak Hulu District Kampar regency, amounting to 76 people. The sampling technique is by simple random sampling by using sloviin formula so that the number of samples in this research are 64 teachers in SMP 4 In Siak Hulu District Kampar Regency and data processing using multiple linear regression test with SPSS program. Based on the results of the test if the data using multiple linear regression test can be taken some conclusions, namely: Work discipline has a very strong role in improving teacher performance in SMP Negeri 4 In Siak Hulu District Kampar regency, communication has a very strong role in improving teacher performance SMP Negeri 4 In Siak Hulu Sub-district, Kampar regency, work discipline and communication together can improve the performance of teachers of SMP Negeri 4 in Siak Hulu sub-district, Kampar regency.
\end{abstract}

Keywords: Discipline; Communication; Performance 


\begin{abstract}
ABSTRAK
Penelitian ini dilakukan pada SMP 4 Di Kecamatan Siak Hulu Kabupaten Kampar. Untuk mengetahui dan menganalisis pengaruh disiplin kerja terhadap kinerja guru SMP Negeri 4 di Kecamatan Siak Hulu Kabupaten Kampar, untuk mengetahui dan menganalisis pengaruh komunikasi terhadap kinerja guru SMP Negeri 4 di Kecamatan Siak Hulu Kabupaten Kampar, untuk mengetahui dan menganalisis pengaruh disiplin kerja dan komunikasi terhadap kinerja guru SMP Negeri 4 di Kecamatan Siak Hulu Kabupaten Kampar.Populasinya adalah semua guru SMP 4 Di Kecamatan Siak Hulu Kabupaten Kampar yang berjumlah 76 orang. Teknik pengambilan sampel adalah dengan cara simple random sampling (acak sederhana) dengan menggunakan rumus sloviin. Jumlah sampel pada penelitian iniberjumlah64 orang guru di SMP 4 Di Kecamatan Siak Hulu Kabupaten Kampar dan pengolahan data menggunakan uji regresi linier berganda.Berdasarkan hasil uji olah data dengan menggunakan uji regresi linier berganda dapat disimpulkan, yaitu: Disiplin kerja mempunyai peranan yang sangat kuat dalam peningkatan kinerja guru di SMP Negeri 4 Di Kecamatan Siak Hulu Kabupaten Kampar, komunikasi mempunyai peranan yang sangat kuat dalam peningkatan kinerja guru SMP Negeri 4 Di Kecamatan Siak Hulu Kabupaten Kampar, disiplin kerja dan komunikasi secara bersama-sama mampu meningkatkan kinerja guru SMP Negeri 4 Di Kecamatan Siak Hulu Kabupaten Kampar.
\end{abstract}

Kata Kunci: Disiplin; Komunikasi; Kinerja

\section{PENDAHULUAN}

Pendidikan saat ini lebih dituntut agar mampu mengembangkan potensi peserta didik. Masing-masing peserta didik memiliki potensi yang berbeda-beda. Potensi peserta didik yang masih terpendam perlu dikembangkan melalui pendidikan dengan mengembangkan aspek kognitif, afektif dan psikomotor. Mengembangkan potensi peserta didik melalui tiga aspek tersebut akan mampu membentuk karakter peserta didik khususnya dan karakter bangsa secara umum. Indonesia dahulu menggunakan sistem sentralisasi pendidikan. Sistem sentralisasi pendidikan ini maksudnya pemerintah pusat memiliki wewenang secara penuh terhadap pendidikan. Misalnya saja dalam hal kebijakan. Pemerintah memiliki wewenang penuh dalam menentukan kebijakan pendidikan. Setiap sekolah hanya tinggal menunggu instruksi dari pemerintah pusat untuk melaksanakan.

Keberhasilan peningkatan mutu sekolah tentunya di lihat dari keberhasilan dalam proses pembelajaran tersebut. Proses pembelajaran merupakan hal pokok dan utama yang harus ada di dalam pendidikan. Oleh karena proses pembelajaran merupakan hal pokok dalam pendidikan yang kemudian akan di jadikan sebagai salah satu penentu dalam peningkatan mutu sekolah, maka diperlukan kinerja yang baik dari guru. Loyalitas yang tinggi, etos kerja dan kegigihan di tuntut ada dalam diri seorang guru agar kinerjanya bagus. Meskipun dalam UURI No. 14 tahun 2005 tentang Guru dan Dosen dikatakan bahwa guru wajib memiliki kualifikasi akademik, kompetensi, sertifikasi pendidik, sehat jasmani dan rohani, serta memiliki kemampuan untuk mewujudkan tujuan pendidikan nasional. Kompetensi tersebut meliputi 
kompetensi pedagogik, kompetensi kepribadian, kompetensi sosial dan kompetensi profesi.

Salah satu permasalahan penting yang dihadapi oleh para kepala sekolah adalah bagaimana dapat meningkatkan kinerja bawahannya sehingga dapat mendukung keberhasilan pencapaian tujuan. Menurut Schermerharn (2003: 7) bahwa pimpinan atau manajer yang baik adalah yang mampumenciptakan suatu kondisi sehingga orangsecara individu atau kelompok dapat bekerjadan mencapai kinerja yang tinggi. Permasalahan peningkatan kinerja erat kaitannyadengan permasalahan bagaimana memotivasi karyawan, bagaimana pengawasan dilakukan, dan bagaimana cara mengembangkan budaya kerja yang efektif sertabagaimana menciptakan lingkungan kerjayang nyaman dan kondusif, agar karyawandapat dan mau bekerja optimal dan sehingga dapat mendukung pencapaian tujuan organisasi.

Menurut Nitisemito dalamDwi Agung Nugroho Arianto (2013) disiplin kerja adalah sikap, tingkah laku dan perbuatan yang sesuai dengan peraturan dariorganisasi baik yang tertulis maupun tidaktertulis. Indikator kedisiplinan kerja adalah sebagai berikut: tujuan dan kemampuan, teladan pimpinan, balas jasa, keadilan, waskat atau pengawasan, sanksi hukuman, ketegasan dan hubungan kemanusiaan.

$$
\text { Mengingat akan sangat }
$$

pentingnya peran seorang guru dalam proses pembelajaran di kelas, maka akan sangat dibutuhkan kinerja guru yang baik agar mampu menyukseskan pembelajaran. Dengan suksesnya pembelajaran di kelas, maka tujuan pendidikan di sekolah dapat tercapai. Sehingga dengan melihat permasalahan tersebut di atas akan sangat mempengaruhi prestasi peserta didik dan tujuan pendidikan di sekolah.

Kinerja seorang guru memperlihatkan tingkat keberhasilannya melakukan fungsi dan tanggung jawabnya sebagai guru sesuai dengan standar-standar yang telah ditetapkan oleh kebijakan dan strategi sekolah tempatnya mengajar. Oleh karena itu penilaian kinerja guru menjadi bagian penting dari proses evaluasi efektivitas sekolah.

Seperti halnya yang terjadi di SMP Negeri 4 Di Kecamatan Siak Hulu Kabupaten Kampar, setiap tahun selalu dilakukan penilaian kinerja guru yang mencakup kepada sejumlah aspek penilaian seperti kedisiplinan, penguasaan konsep (materi), pengelolaan kelas, dan evaluasi serta tindak lanjut sebagaimana yang ditunjukkan pada tabel berikut ini:

Tabel 1.1: Perkembangan Hasil Penilaian Kinerja Guru

\begin{tabular}{|c|c|c|c|c|c|c|}
\hline \multirow{2}{*}{$\begin{array}{c}\text { Tah } \\
\text { un }\end{array}$} & $\begin{array}{c}\text { Kedispli } \\
\text { nan }\end{array}$ & $\begin{array}{c}\text { PenguasaanK } \\
\text { onsep }\end{array}$ & $\begin{array}{c}\text { Pengelolaan } \\
\text { Kelas }\end{array}$ & $\begin{array}{c}\text { Evaluasi\&Tindak } \\
\text { Lanjut }\end{array}$ & $\begin{array}{c}\text { Targe } \\
\text { Rata- } \\
\text { Kine } \\
\text { Kine } \\
\text { rja }\end{array}$ & $\begin{array}{c}\text { Kiner } \\
\text { ja } \\
\text { Mini } \\
\text { mal }\end{array}$ \\
\hline 2012 & 78 & 75 & & & 78 & 86 \\
2013 & 80 & 80 & 81 & 76 & 79 & 86 \\
2014 & 75 & 77 & 71 & 74 & 76 & 86 \\
2015 & 72 & 75 & 81 & 72 & 75 & 86
\end{tabular}


KriteriaHasilPenilaian

86-100 : AmatBaik
$71-85$
: Baik
55-70
: CukupBaik
$<55$
: KurangBaik
Sumber: SMP Negeri 4 Siak Hulu Kabupaten Kampar

Berdasarkan Tabel 1.1 tampak bahwa skor penilaian kinerja guru yang di lakukan secara internal oleh manajemen SMP Negeri 4 Di Kecamatan Siak Hulu Kabupaten Kampar mengalami fluktuasi di setiap tahunnya, baik yang terjadi pada setiap indikator maupun pada skor rata-rata kinerja secara umum para guru. Skor rata-rata paling tinggi terjadi pada tahun 2016 yang mencapai 80, atau masuk dalam kategori skor kinerja yang "Baik". Namun demikian, yang menjadi keinginan manajemen sekolah adalah agar skor rata-rata kinerja tersebut minimal bisa mencapai skor rata-rata 86 (Amat Baik) setiap tahunnya.

Kinerja seorang guru tentu tidak datang dengan sendirinya, karena di butuhkan sejumlah faktor yang mempengaruhinya, sehingga perlu di perhatikan bagaimana disiplin para guru terutama dalam mengajar di sekolah. Pendisiplinan merupakan tindakan organisasi yang tidak mengakibatkan seorang pegawai kehilangan sesuatu dari organisasi. Pendisiplinan bersifat konstruktif atau memperbaiki karena pendisiplinan merupakan bagian dari proses pembelajaran (Thoha miftah, 2008).

Untuk mewujudkan tujuan suatu organisasi, sebuah peraturan sangatlah di perlukan dalam menciptakan suatu kedisiplinan bagi para pegawai. Dengan adanya peraturan dan pendisiplinan, semangat kerja dan kinerja pegawai akan meningkat. Pegawai akan lebih berhati-hati dan akan lebih disiplin dalam menjalankan pekerjaannya. Peraturan itu sendiri harus bersifat tegas bagi yang melanggarnya agar kedisiplinan perusahaan tersebut dapat dikatakan baik dan kinerja pegawai meningkat.

Dari hasil pantauan dilapangan, fenomena yang ada adalah disiplin kerja para guru yang terus menurun, hal ini terlihat dari banyaknya para guru yang datang terlambat dan pulang lebih awal dari waktu yang telah ditentukan, sehingga dapat menghambat kinerja dari para guru. Berdasarkan fenomena tersebut sudah cukup menunjukkan bahwa betapa rendahnya kinerja para guru di lingkungan SMP Negeri 4 Di Kecamatan Siak Hulu Kabupaten Kampar.

Selain faktor disiplin kerja, ternyata komunikasi juga sangat berpengaruh terhadap kinerja guru. Komunikasi didalam organisasi merupakan salah satu cara untuk mencapai tujuan yang telah direncanakan (Pace dan Faules , 2009). Sebagai bentuk penilaian komunikasi organisasi yang berjalan, bisa dilihat dari kinerja yang dicapai. Apabila komunikasi disuatu organisasi berjalan dengan baik, maka akan berpengaruh terhadap hasil kerja yang baik pula. Begitu juga sebaliknya apabila apabila komunikasi organisasi tidak berjalan dengan baik, maka kinerja akan menurun. Jadi untuk menilai komunikasi organisasi yang berjalan 
diperlukan adanya penilaian kinerja. Komunikasi yang efektif bergantung dari hubungan para guru yang dibangun berdasarkan kepercayaan dan suasana organisasi yang kondusif karena komunikasi yang baik dapat menimbulkan rasa tenang dan nyaman dalam bekerja.

Komunikasi yang baik antara pimpinan dengan bawahan sangat menentukan adanya hubungan yang baik antara keduanya. Bila komunikasi terjalin dengan baik maka tujuan perusahaan dapat tercapai dengan baik pula. Komunikasi internal dapat meningkatkan kinerja guru karena guru merasa diperhatikan oleh atasannya karena itu seorang pimpinan yang harus mampu membangun komunikasi dengan bawahannya agar tercipta hubungan yang harmonis. Apabila guru merasa senang maka pekerjaan yang dilakukan akan memperoleh hasil yang baik.

Kinerja adalah suatu tampilan keadaan secara utuh atas organisasi selama periode tertentu, merupakan hasil atau prestasi yang di pengaruhi oleh kegiatan operasional organisasi dalam memanfaatkan sumber daya yang di miliki (Rivai, 2008). Kinerja sebagai pencapaian atau prestasi seseorang berkaitan dengan tugas yang di berikan dan hasil kerja yang dapat dicapai oleh seseorang atau sekelompok orang dalam suatu organisasi sesuai dengan wewenang dan tanggung jawab masingmasing, dalam upaya mencapai tujuan organisasi bersangkutan secara legal, tidak melanggar hukum dan sesuai dengan moral etika (Sedarmayanti, 2009).

Keberadaan guru dalam melaksanakan tugas dan kewajibannya tidak lepas dari pengaruh faktor internal maupun eksternal yang membawa dampak pada perubahan kinerja guru. Adapun faktor-faktor yang mempengaruhi kinerja yaitu: 1)Faktor individu (personal factors). Faktor individu berkaitan dengan keahlian, motivasi dan komitmen. 2) Faktor kepemimpinan (leadership factors). Faktor kepemimpinan berkaitan dengan kualitas dukungan dan pengarahan yang diberikan oleh pimpinan. 3) Faktor kelompok/rekan kerja (team factors). Faktor kelompok/rekan kerja berkaitan dengan kualitas dukungan yang diberikan oleh rekan kerja. 4) Faktor sistem (system factors). Faktor sistem berkaitan dengan metode kerja yang ada dan fasilitas yang disediakn oleh organisasi. 5) Faktor situasional (contekstual/situasional factors). Faktor situasi berkaitan dengantekanan dan perubahan lingkungan, baik lingkungan internal maupun eksternal.

Faktor-faktor yang dapat mempengaruhi kinerja guru adalah: 1) Kepribadian dan dedikasi, 2) Pengembangan profesi, 3) Kemampuan mengajar, 4) Hubungan dan komunikasi, 5) Hubungan dengan masyarakat, 6) Kedisiplinan, 7) Kesejahteraan, 8) Iklim kerja (Muhlisin, 2009). Menurut Sudrajat adapun indikator-indikator kinerja guru adalah:1) Menguasai karakteristik peserta didik. 2) Menguasasi teori belajar dan prinsip-prinsip pembelajaran yang mendidik. 3) Pengembangan kurikulum. 4) Kegiatan pembelajaran yang mendidik (Akhmad Sudrajat, 2008).

Menurut Hasibuan disiplin adalah kesadaran dan kesediaan seseorang menaati semua peraturan organisasi dan norma-norma sosial yang berlaku. Kesadaran disini merupakan sikap seseorang yang secara sukarela menaati semua peraturan dan sadar akan tugas dan tanggung jawabnya. Jadi, dia akan mematuhi atau mengerjakan semua tugasnya dengan baik, bukan atas paksaan. Sedangkan kesediaan adalah 
suatu sikap, tingkah laku, dan perbuatan seseorang yang sesuai dengan peraturan perusahaan, baik yang tertulis maupun tidak (Hasibuan, 2014).

Menurut Mangkunegara (2008) bahwa disiplin mempunyai 3 (tiga) macam bentuk, yaitu:

1. Disiplin Preventif

Disiplin preventif upaya untuk menggerakkan guru dalam mengikuti dan mematuhi pedoman kerja, aturan-aturan yang telah digariskan oleh perusahaan.

2. Disiplin Korektif

Disiplin korektif adalah upaya menggerakkan guru dalam menyatukan suatu peraturan dan mengarahkan untuk tetap mematuhi peraturan sesuai dengan pedoman yang berlaku pada perusahaan.

3. DisiplinProgesif

Disiplin progresif memberikan hukuman-hukuman yang lebih berat terhadap pelanggaran yang berulang.

\section{METODOLOGI PENELITIAN}

Penelitian ini dilaksanakan di Sekolah SMP 4 Siak Hulu Kabupaten Kampar. Penelitian ini menggunakan penelitian eksplanatori (explanatory research) yang menjelaskan kedudukan variabel-variabel yang akan diteliti dan untuk mengetahui hubungan antara satu variabel dengan variabel lainnya kemudian menguji hipotesis yang telah dirumuskan (Arikunto 2010:161). Populasi merupakan keseluruhan objek yang akan diteliti. Dalam penelitian ini populasinya adalah semua guru SMP 4 Di Kecamatan Siak Hulu Kabupaten Kampar yang berjumlah 76 orang. Teknik pengambilan sampel adalah dengan cara simple random sampling (acak sederhana) menggunakan rumus Slovin sebagaiberikut:

$$
\begin{aligned}
& \mathrm{n}=\frac{N}{1+N \cdot \mathrm{e}^{2}} \\
& \mathrm{n}=\frac{76}{1+76(0,05)^{2}} \\
& =63,86(\text { Dibulatkan menjadi } 64)
\end{aligned}
$$

Keterangan:

$\mathrm{n}=$ jumlah sampel

$\mathrm{N}=$ Jumlah Populasi

$\mathrm{d}=$ Tingkat Keyakinan yang Digunakan $(5 \%)$

Sehingga jumlah sampel pada penelitian ini adalah sebanyak 64 orang guru di SMP 4 Di Kecamatan Siak Hulu Kabupaten Kampar.Dalam menganlisis data yang di peroleh, penulis menggunakan metode deskriptif kuantitatif, yaitu suatu cara yang dapat menjelaskan hasil penelitian yang ada dengan menggunakan persamaan rumus matematis dan menghubungkannya dengan teori yang ada, kemudian di tarik kesimpulan.

Pengukuran variabel-variabel yang terdapat dalam model analisis penelitian ini bersumber dari jawaban atas pertanyaan yang terdapat dalam angket. Karena semua jawaban tersebut bersifat deskriptif, sehingga diberi nilai agar menjadi data kuantitatif. Penentuan nilai jawaban untuk setiap pertanyaan menggunakan metode Skala Likert dengan pembobotan setiap pernyataan sebagai berikut:

a. Jika memilih jawaban Sangat Setuju (SS), maka diberi nilai 5

b. Jika memilih jawaban Setuju (S), maka diberi nilai 4

c. Jika memilih jawaban Cukup Setuju (CS), maka diberi nilai 3

d. Jika memilih jawaban Tidak Setuju (TS), maka diberi nilai 2

e. Jika memilih jawaban Sangat Tidak Setuju (STS), maka diberi nilai 1 
Dari hasil tanggapan responden tersebut maka akan diperoleh interval rata-rata variabel sebagai berikut:

$$
\begin{aligned}
& \text { interval }=\frac{\text { nilai tertinggi-nilai terendah }}{5} \\
& \text { interval }=\frac{5-1}{5}=0,8
\end{aligned}
$$

Tabel 3.1 Interval Rata-Rata Variabel

\begin{tabular}{|c|c|}
\hline Interval rata-rata & Kategori \\
\hline $4,20-5,00$ & Sangat Baik \\
$3,40-4,19$ & Baik \\
$2,60-3,39$ & Cukup Baik \\
$1,80-2,59$ & Tidak Baik \\
$1,00-1,79$ & Sangat Tidak Baik \\
\hline
\end{tabular}

Sumber: Data olahan, 2017

Teknik yang di gunakan penulis dalam pengumpulan data penelitian ini adalah:

a. Interview (Wawancara), yaitu merupakan prosedur pengumpulan data dengan mengajukan pertanyaan-pertanyaan kepada pemimpin perusahaan serta guru yang berhubungan dengan masalah yang penulis teliti.

b. Questioner (Angket), yaitu suatu cara pengumpulan data melalui daftar pertanyaan yang telah penulis siapkan yang ditujukan kepada responden yang akan dijadikan sampel. Dengan mencatat data yang tersedia yang berhubungan dengan permasalahan penelitian yang ada.

\section{HASIL PENELITIAN DAN PEMBAHASAN}

Suatu instrument di katakan valid jika pernyataan pada suatu instrument mampu untuk mengungkapkan sesuatu yang akan di ukur oleh kuesioner tersebut. Pada uji validitas, sampel yang digunakan sebanyak 64 responden. Pengujian validitas di lakukan dengan membandingkan nilai korelasi $\mathrm{r}$ hitung dengan $r$ tabel, dengan kriteria pengujian:

1. Jika $r$ hitung $\geq r$ tabel maka item-item pernyataan di nyatakan valid

2. Jika $r$ hitung $<r$ tabel maka item-item pernyataan di nyatakan tidak valid.

Nilai $r$ tabel di peroleh denga persamaan $\mathrm{N}-2=64-2=62$ (lihat tabel $\mathrm{r}$ dengan df 62$)=0,246$. Nilai $r$ hitung dalam uji ini adalah pada kolom Item Total Statistics (Corrected Item - Total Correlation) dan di ketahui nilai $\mathrm{r}$ hitung $\geq 0,246$. Artinya seluruh itemitem variabel di nyatakan valid. Nilai uji validitas dapat di lihat pada tabel berikut ini:

Tabel 5.5: Hasil Uji Validitas Instrument

\begin{tabular}{|c|c|c|c|c|}
\hline Variabel & Item & r hitung & r table & Keterangan \\
\hline & 1 & 0,580 & 0,246 & Valid \\
KINERJA & 2 & 0,620 & 0,246 & Valid \\
(Y) & 3 & 0,490 & 0,246 & Valid \\
& 4 & 0,475 & 0,246 & Valid \\
& 5 & 0,557 & 0,246 & Valid \\
& 6 & 0,304 & 0,246 & Valid
\end{tabular}




\begin{tabular}{|c|c|c|c|c|}
\hline Variabel & Item & r hitung & r table & Keterangan \\
\hline & 7 & 0,390 & 0,246 & Valid \\
\hline & 8 & 0,375 & 0,246 & Valid \\
\hline & 9 & 0,267 & 0,246 & Valid \\
\hline & 10 & 0,273 & 0,246 & Valid \\
\hline & 11 & 0,698 & 0,246 & Valid \\
\hline & 12 & 0,679 & 0,246 & Valid \\
\hline & 13 & 0,607 & 0,246 & Valid \\
\hline & 14 & 0,575 & 0,246 & Valid \\
\hline & 15 & 0,597 & 0,246 & Valid \\
\hline & 16 & 0,680 & 0,246 & Valid \\
\hline & 17 & 0,590 & 0,246 & Valid \\
\hline & 18 & 0,565 & 0,246 & Valid \\
\hline & 19 & 0,647 & 0,246 & Valid \\
\hline & 20 & 0,509 & 0,246 & Valid \\
\hline & 1 & 0,722 & 0,246 & Valid \\
\hline & 2 & 0,670 & 0,246 & Valid \\
\hline & 3 & 0,558 & 0,246 & Valid \\
\hline & 4 & 0,606 & 0,246 & Valid \\
\hline & 5 & 0,554 & 0,246 & Valid \\
\hline & 6 & 0,511 & 0,246 & Valid \\
\hline & 7 & 0,621 & 0,246 & Valid \\
\hline & 8 & 0,661 & 0,246 & Valid \\
\hline & 9 & 0,608 & 0,246 & Valid \\
\hline \multirow{21}{*}{$\begin{array}{l}\text { DISIPLIN } \\
\quad\left(\mathrm{X}_{1}\right)\end{array}$} & 10 & 0,699 & 0,246 & Valid \\
\hline & 11 & 0,689 & 0,246 & Valid \\
\hline & 12 & 0,682 & 0,246 & Valid \\
\hline & 13 & 0,690 & 0,246 & Valid \\
\hline & 14 & 0,463 & 0,246 & Valid \\
\hline & 15 & 0,409 & 0,246 & Valid \\
\hline & 16 & 0,481 & 0,246 & Valid \\
\hline & 17 & 0,628 & 0,246 & Valid \\
\hline & 18 & 0,714 & 0,246 & Valid \\
\hline & 19 & 0,649 & 0,246 & Valid \\
\hline & 20 & 0,290 & 0,246 & Valid \\
\hline & 1 & 0,740 & 0,246 & Valid \\
\hline & 2 & 0,671 & 0,246 & Valid \\
\hline & 3 & 0,651 & 0,246 & Valid \\
\hline & 4 & 0,339 & 0,246 & Valid \\
\hline & 5 & 0,599 & 0,246 & Valid \\
\hline & 6 & 0,551 & 0,246 & Valid \\
\hline & 7 & 0,670 & 0,246 & Valid \\
\hline & 8 & 0,569 & 0,246 & Valid \\
\hline & 9 & 0,612 & 0,246 & Valid \\
\hline & 10 & 0,264 & 0,246 & Valid \\
\hline \multirow{3}{*}{$\begin{array}{l}\text { KOMUNIKASI } \\
\left(\mathbf{X}_{2}\right)\end{array}$} & 11 & 0,638 & 0,246 & Valid \\
\hline & 12 & 0,761 & 0,246 & Valid \\
\hline & 13 & 0,751 & 0,246 & Valid \\
\hline
\end{tabular}




\begin{tabular}{|c|c|c|c|c|}
\hline Variabel & Item & r hitung & $\mathbf{r}$ table & Keterangan \\
\hline & 14 & 0,596 & 0,246 & Valid \\
& 15 & 0,670 & 0,246 & Valid \\
\hline
\end{tabular}

\section{Sumber: Data Olahan, 2018}

Berdasarkan Tabel 5.6 dapat di lihat bahwa nilai $r$ hitung pada jawaban responden terhadap pertanyaan semua variabel di nyatakan valid karena $r$ hitung $\geq \mathrm{r}$ table, maka dapat disimpulkan bahwa rata-rata item-item dari tiga variabel di nyatakan terukur.

Tabel 5.6: Hasil Uji Reliabilitas Instrument

\begin{tabular}{|l|c|c|c|}
\hline \multicolumn{1}{|c|}{ Variabel } & $\begin{array}{c}\text { Standar } \\
\text { Koefisien Alpha }\end{array}$ & $\begin{array}{c}\text { Cronbach's } \\
\text { Alpha }\end{array}$ & Keterangan \\
\hline Kinerja & 0,60 & 0,886 & Reliabel \\
Disiplin & 0,60 & 0,917 & Reliabel \\
Komunikasi & 0,60 & 0,908 & Reliabel \\
\hline
\end{tabular}

Sumber: Data Olahan, 2018

Berdasarkan Tabel 5.7 diketahui hasil pengujian nilai reliabilitas ketiga variabel berada di atas angka 0,60. Artinya adalah bahwa alat ukur yang digunakan dalam penelitian ini reliabel.

Berdasarkan hasil penelitian ini telah membuktikan bahwa tidak terdapat adanya heterokedastisitas, sehingga menunjukkan bahwa tidak terjadinya perbedaan antara variasi residual dari kinerja guru yang di akibatkan oleh variabel penelitian yang mempengaruhinya.

Berdasarkan hasil pengolahan data dengan melihat nilai VIF dengan formula VIF =di mana VIF, Disiplin Kerja $\left(\mathrm{X}_{1}\right)$ sebesar 1,000 dan Komunikasi $\left(\mathrm{X}_{2}\right)$ sebesar 1,000. sehingga dapat di simpulkan bahwa kedua variabel bebas tersebut tidak terdapat multikolinearitas karena nilai VIF (Varians Inflation Factor) nya lebih kecil dari 10.

Tabel 5.7: Hasil Uji Regresi Linear Berganda

Coefficients $^{\mathbf{a}}$

\begin{tabular}{|c|c|c|c|c|}
\hline \multirow[t]{2}{*}{ Model } & \multicolumn{2}{|c|}{ Unstandardized Coefficients } & \multirow[t]{2}{*}{$\mathrm{T}$} & \multirow[t]{2}{*}{ Sig. } \\
\hline & B & Std. Error & & \\
\hline (Constant) &, 123 & ,242 & ,507 & ,614 \\
\hline 1 Disiplin & ,870 &, 060 & 14,423 &, 000 \\
\hline Komunikasi & 109 & 043 & 2,546 & 013 \\
\hline
\end{tabular}

a. Dependent Variable: Kinerja

Sumber: Data Olahan, 2018

Dari tabel 5.8, maka dapat di ketahui persamaan regresi linier berganda sebagai berikut:

$\mathrm{Y}=\mathrm{a}+\mathrm{b}_{1} \mathrm{X}_{1}+\mathrm{b}_{2} \mathrm{X}_{2}+\mathrm{e}$

Kinerja $=0,123+0,870+0,109+\mathrm{e}$

Arti adalah:
1. Nilai konstanta (a) sebesar 0,123 Artinya adalah apabila disiplin dan komunikasi diasumsikan nol (0), maka kinerja bernilai 0,123 .

2. Nilai koefisien regresi variabel 
disiplin kerja sebesar 0,870 . Artinya adalah bahwa setiap peningkatan disiplin sebesar satu (1) satuan maka akan meningkatkan nilai kinerja sebesar 0,870 dengan asumsi variabel lain tetap.

3. Nilai koefisien regresi variabel komunikasi sebesar 0,109. Artinya adalah bahwa setiap peningkatan komuikasi sebesar satu (1) satuan maka akan meningkatkan nilai kinerja sebesar 0,109 dengan asumsi variabel lain tetap.

4. Standar error (e) merupakan variabel acak dan mempunyai distribusi probabilitas. Standar error (e) mewakili semua faktor yang mempunyai pengaruh terhadap $\mathrm{Y}$ tetapi tidak dimasukkan dalam persamaan.

Disiplin kerja dan komunikasi merupakan faktor yang sangat penting bagi organisasi, dengan bagusnya disiplin kerja dan komunikasi, maka akan meningkatkan kinerja organisasi tersebut. Begitu juga halnya yang terjadi pada guru di SMP Negeri 4 Di Kecamatan Siak Hulu Kabupaten Kampar, setelah di teliti ternyata terbukti disiplin kerja dan komunikasi secara simultan berpengaruh positif dan signifikan terhadap kinerja guru. Dengan hasil ini maka hipotesis dalam penelitian ini dapat di terima. Jadi dapat di ketahui bahwa dengan rendahnya disiplin dan komunikasi guru SMP Negeri 4 Di Kecamatan Siak Hulu maka akan menyebabkan kinerja guru menurun.Disiplin kerja guru yang ada pada SMP Negeri 4 Siak Hulumasih rendah. hal ini terlihat dari banyaknya para guru yang datang terlambat dan pulang lebih awal dari waktu yang telah di tentukan, sehingga dapat menghambat kinerja dari para guru. Dan dari pengujian statistik (Uji t) yang dilakukan di ketahui bahwa hipotesis yang menyatakan disiplin berpengaruh signifikan terhadap kinerja guru pada SMP Negeri 4 Siak Huludapat diterima.

Komunikasi kerja yang ada pada SMP Negeri 4 Siak Hulumasih belum maksimal. Apabila komunikasi di suatu organisasi berjalan dengan baik, maka akan berpengaruh terhadap hasil kerja yang baik pula. Begitu juga sebaliknya apabila apabila komunikasi organisasi tidak berjalan dengan baik, maka kinerja akan menurun. Jadi untuk menilai komunikasi organisasi yang berjalan di perlukan adanya penilaian kinerja. Komunikasi yang efektif bergantung dari hubungan para guru yang di bangun berdasarkan kepercayaan dan suasana organisasi yang kondusif karena komunikasi yang baik dapat menimbulkan rasa tenang dan nyaman dalam bekerja. Hal ini terlihat dari hasil pra survey yang penulis lakukan, di temui bahwa komunikasi para guru di SMP Negeri 4 Di Kecamatan Siak Hulu Kabupaten Kampar masih kurang harmonis sehingga membuat kinerja para guru menurun. Hal ini sangat tampak dari kurang saling terbukanya para guru terhadap penyampaian informasi pekerjaan, kurang saling mendukungnya para guru dalam bekerja, dan para guru belum sepenuhnya merasa memiliki kesamaan tujuan dalam bekerja. Dari pengujian statistik (Uji t) yang di lakukan, di ketahui bahwa hipotesis yang menyatakan komitmen organisasi berpengaruh signifikan terhadap kinerja guru pada SMP Negeri 4 Di Kecamatan Siak Hulu Kabupaten Kampar dapat di terima. Menurut penulis, komunikasi berpengaruh terhadap kinerja guru, karena pada SMP Negeri 4 Di 
Kecamatan Siak Hulu Kabupaten Kampar ini di ketahui bahwa benar komunikasi guru itu masih belum baik sehingga membuat kinerjanya menurun.

\section{SIMPULAN DAN REKOMENDASI}

1. Disiplin kerja dan komunikasi secara bersama-sama mampu meningkatkan kinerja guru SMP Negeri 4 Di Kecamatan Siak Hulu Kabupaten Kampar. Sehingga dapat disimpulkan bahwa apabila guru telah berdisiplin dalam bekerja dan komunikasi antar sesama guru telah bagus maka kinerja guru juga akan meningkat.

2. Disiplin kerja mempunyai peranan yang sangat kuat dalam peningkatan kinerja guru di SMP Negeri 4 Di Kecamatan Siak Hulu Kabupaten Kampar.

3. Komunikasi mempunyai peranan yang sangat kuat dalam peningkatan kinerja guru SMP Negeri 4 Di Kecamatan Siak Hulu Kabupaten Kampar

Berdasarkan pada beberapa simpulan, maka dapat di berikan rekomendasi sebagai berikut:

1. Sekolah harus mampu meningkatkan kinerja para guru seperti memberikan pemahaman yang berupa diklat atau pelatihan untuk menguasai konsep atau materi yang di ajarkan, menguasai kelas dengan baik, mampu mengevaluasi siswa dengan objektif, dan supaya guru mampu melakukan tindakan perubahan setelah memperoleh hasil evaluasi pembelajaran siswa.

2. Dalam meningkatkan disiplin kerja guru diharapkan kepada pimpinan SMP Negeri 4 Di Kecamatan Siak Hulu Kabupaten Kampar agar memberikan motivasi positif seperti memberi penghargaan (reward) kepada guru yang selalu menaati peraturan dan memberikan motivasi negatif seperti memberi sanksi kepada guru berupa pemotongan tunjangan bagi guru yang kerap melanggar peraturan. Dengan demikian diharapkan guru selalu disiplin dalam bekerja dan mau bertanggungjawab terhadap pekerjaannya.

3. Dalam meningkatkan komunikasi antar sesama guru diharapkan agar pimpinan lebih memberi perhatian atau ajakan supaya guru mau berpartisipasi dan bersemangat untuk aktif dalam mengembangkan organisasi sekolah dan mampu menjalankan profesi keguruannya dengan optimal.

4. Diharapkan kepada penelitian selanjutnya untuk melakukan kajian-kajian lebih lanjut mengenai faktor-faktor lain yang mempengaruhi kinerja guru berdasarkan karakteristik serta analisis yang berbeda.

\section{DAFTAR PUSTAKA}

Akhmad Sudrajat. (2008). Pengertian Pendekatan, Strategi, Metode, Teknik danModel Pembelajaran. Bandung: Sinar Baru Algensindo

Arikunto. (2010). Prosedur Penelitian suatu Pendekatan Praktek.Jakarta: Rineka cipta.

Dwi Agung Nugroho Arianto. (2013). Pengaruh Kedisiplinan, Lingkungan Kerja Dan Budaya Kerja Terhadap Kinerja Tenaga Pengajar. Jurnal Economia, Vol 9, No 2. Universitas Islam Nahdlatul Ulama Jepara, Indonesia. 
Eka Permata,Hasnah Faizah dan Maruzki. (2107). Pengaruh Kepemimpinan Kepala Sekolah dan Komunikasi Interpersonal terhadap Kinerja Guru SMP SeKecamatan Kuok Kabupaten Kampar. Jurnal Manajemen Pendidikan, Vol.2 No.3. Program Studi Manajemen Pendidikan Pasca Sarjana Universitas Riau.

Fitria, Hasna Faizah dan Azhar. (2016). Hubungan antara Motivasi Kerja dan Kepuasan Kerja dengan Kinerja Guru di SMK Negeri Se-Kecamatan Rambah Kabupaten Rokan Hulu. Jurnal Manajemen Pendidikan, Vol. 2 No.3. Program Studi Manajemen Pendidikan Pasca Sarjana Universitas Riau.

Hasibuan. (2014). Manajemen Sumber Daya Manusia. Jakarta: Bumi aksara.

Hendri Susanto. (2014). Hubungan antara Komunikasi Interpersonal dan Kompetensi dengan Komitmen Organisasi Guru SD Swasta Gugus I Rayon KecamatanPayung Sekaki. Jurnal Manajemen Pendidikan, Vol. 2 No. 3.Program Studi
Manajemen Pendidikan

Pascasarjana Universitas Riau

Mangkunegara. (2008). Manajemen Sumber Daya Manusia. Jakarta: Rajawali Pers.

Muhlisin. (2009). Profesionalisme Kinerja Guru Masa Depan. Bandung: Remaja Rosdakarya.

Pace dan Faules. (2008). Komunikasi Organisasi. Bandung: PT. Remaja Rosdakarya.

Rivai. (2008). Manajemen Sumber Daya Manusia untuk Perusahaan.Jakarta: Rajawali Pers.

Schermenharn, J.R. (2003). Manajemen (Edisi Bahasa Indonesia). Yogyakarta: Penerbit Andi.

Sedarmayanti. (2009). Manajemen Sumber Daya Manusia. Bandung: Mandar Maju.

Thoha miftah. (2008). Manajemen Kepegawaian Sipil Indonesia. Jakarta: Kencana.

Wibowo. (2008). Manajemen Sumber Daya Manusia. Jakarta: Rajawali Pers. 